\title{
Frequency of Sportive Injuries in Amateur Athletes and Factors Affecting Injuries
}

\author{
Egemen ERMIŞ̧ ${ }^{1}$ Osman İMAMOĞLU ${ }^{1}$, Arif SATICI ${ }^{1}$
}

${ }^{1}$ Ondokuz Mayıs University, Yaşar Doğu Faculty of Sport Sciences, Samsun, Turkey

Address Correspondence to A, Satıcı, e-mail: arifsatici@gmail.com.

\begin{abstract}
It is possible to face injury risk whether the sport is recreational or contest purpose based. Exposure to injury can be attributed to many factors (field, competitor, etc.). Because of an injury amateur or elite athletes may move away from their sporting lives. This study aims to investigate frequency of sport injuries and factors affecting injuries to amateur athletes in Samsun region. 666 amateur athletes serving in various amateur sports clubs in Samsun province were selected randomly. 462 participants were men, 204 were women. 240 athletes in individual sports branches (wrestling, table tennis, taekwondo, wrist wrestling, wushu, athletics), and 426 athletes in team sports (basketball, football, handball, volleyball) constitute the sample. The subjects completed a sports injury survey developed by the researchers. X2 was used for statistical analysis of the data. Participants were most often $(44.6 \%)$ faced with a sprain injury. The most injured areas were the wrists and ankles, with a ratio of $36.4 \%$. The period of disability was found to be $0-1$ days with $62.8 \%$. The injured rested for 7 days or less with a ratio of $57.4 \%$. Athletes were found to exercise partially intensively during injury (52.1\%). Treatment applied during injury was mostly performed by the self, the doctor and others. Among the causes of injuries, opponent player was found to be the leading factor with $33.6 \%$. It was found that in amateur sports, gender and type of sport had an effect on injuries. Regional preventive precautions may be taken to avoid injuries. Trainings and seminars can be given to coaches and athletes to reduce injuries in individual and team sports. In addition, medical personnel can be provided to amateur sports clubs with the support of the state.
\end{abstract}

Key words: Sports, Amateur, Injury.

\section{INTRODUCTION}

Sport is defined as the set of movements that develop an individual's state of health, physical ability and performance (1). During these movements, that is, sportive activities, athletes are faced with various risks of injury (2). Thus, all kinds of damage that occur during sportive activities can be called sport injury (10), and sport injury is identified as a major public health problem in the Western world (5). Dvorak and Junge define sport injury as an event that occurs during training or a match that causes the sports player to be absent from the next training session or match (7). Incidence and distribution of sports related injuries vary based on sport affiliation, participation level, gender and player position (18). When the reasons which cause sport injuries are examined, they can be listed as personal reasons such as age and gender, physical structure and predisposition to sport branch, psychomotor development, psycho-social reasons, past injuries and insufficient rehabilitation, insufficient sport technique and insufficient warmup and external reasons such as type of sport, physical area in which the sport is done, sports equipment, coach and training planning, climatic and environmental conditions, duration of sportive activity, the role of opponents and team mates, referee and activity rules (13). However, the definitions, diagnoses, and categorizations of injuries differ among studies, making comparison of results difficult (16).

It can be stated that every sport branch has specific rules or practices; however, it can also be stated that none of the differences has eliminated the state of injury in sport. Thus, it can be stated that no matter which sport activity is chosen, it is inevitable for the athlete to be exposed to small or big injuries (15). Regardless of the sport branch, training itself, which is a prerequisite to reach high performance, is a life-threatening practice. Any health problem has physical, psychological and economic consequences. Most of the time, following the injury of an athlete, only training and competition losses are remembered. However, when discussed in a wider perspective, the price paid is much higher than thought, considering first the immediate circle (the athlete, athlete's family and coach) and then the remote circle (the citizens of the country the athlete 
lives in and even the world sport public opinion) (8). The serious consequences that may result from injuries among the youth population (including, but not limited to, early bone disease, high medical costs, and a decrease in physical activity) are responsible for the heightened awareness to this topic (3). In line with all the expressions stated, it can be said that it is important to conduct various studies on sports injuries since this is an issue that appeals to a wide circle.

To reduce sports injury and better educate the public, understanding the risk factors is essential for prevention (12). However, there are limited numbers of studies which focus on amateurs. Therefore, the aim of this study is to research the frequency of sport injuries and the factors influencing injuries in amateur athletes of Samsun region.

\section{MATERIAL AND METHOD}

In order to find out the frequency of sport injuries and the factors influencing injuries in amateur athletes, a total of 666 amateur athletes in Samsun region chosen with random sampling method filled in a questionnaire form prepared by the researchers. The questionnaire was constructed based on the objectives of the study and each question in the questionnaire included various variables depending on the subject. Events which prevented amateur athletes from participating in sport at least for one day were defined as sport injury. The first part of the questionnaire includes demographic information such as age, gender, sport branch, height and weight of amateur athletes. In the second part, there were questions about risk factors influencing sport injuries, such as previous injuries and warm-up level. The third part included information such as post-injury resting times, postinjury injured time, amateur athletes' state of training, injury types, area of injury, and the treatment methods applied by the athletes.

A total of 666 athletes, 462 males and 204 females, chosen randomly as subjects were in various sport clubs in the province of Samsun. The sample of the study consists of 240 athletes in individual sport branches (wrestling, table tennis, taekwondo, arm wrestling, wushu, athleticism) and 426 athletes in team sports (basketball, football, handball, volleyball). Arithmetic averages, percentage frequency distributions and X2 were used in the statistical analysis of data.

\section{RESULTS}

Table 1 shows the distributions of sport injuries by age, height and weight. Average age of the athletes was found as 21,09 years. Average height of the athletes was found as $174,34 \mathrm{~cm}$, while average weight was found as $68,11 \mathrm{~kg}$.

Table 1. Distributions of sport injuries by age, height and weight in amateur athletes

\begin{tabular}{lccccc}
\hline $\begin{array}{l}\text { Paramet } \\
\text { ers }\end{array}$ & N & Ave. & $\begin{array}{c}\text { St } \\
\text { dev }\end{array}$ & Min & Max \\
\hline $\begin{array}{l}\text { Age } \\
\text { (years) }\end{array}$ & 666 & 21,09 & 3,04 & 18,00 & 36,00 \\
\hline $\begin{array}{l}\text { Height } \\
\text { (cm) }\end{array}$ & 666 & 174,34 & 8,34 & $\begin{array}{c}154,0 \\
0\end{array}$ & 196,00 \\
\hline $\begin{array}{l}\text { Weight } \\
\text { (kg) }\end{array}$ & 666 & 68,11 & 12,05 & 45,00 & 120,00 \\
\end{tabular}

Table 2 shows the data about risk factors influencing sport injuries by gender and sport branch. There is a significant difference at the level of $p<0,001$ between risk factors influencing sport injuries by gender $(p<0,05)$. It can be seen that the most effective risk factor in terms of gender was opponent player $(33,6 \%)$, while the least effective risk factor was insufficient flexibility and other risk factors (shoes worn, level of education, environmental factors, etc.) $(2,9 \%)$. It can be said that male athletes experience injuries due to characteristics of the sport the most (32,5\%). When it is also considered that men view sport as a power indicator, it can also be said that they adopt the power-based aspects of the sport branch. Thus, in this case, the type of sport can have caused sport injuries to have a higher average when compared with the other parameters. It can be seen that injuries occur due to the frequency of training the least $(1,3 \%)$. It can be seen that men do not experience much negativity in terms of injuries due to training frequency. The reason for this may be the fact that men have a resistant physique and that men have a higher speed of post-training recovery when compared with women. It can be seen that the risk factor causing the highest number of injuries is opponent player $(41,2 \%)$. The risk factors causing the least number of injuries are insufficient flexibility and other risk factors (shoes worn, level of education, environmental factors, etc.) $(2,9 \%)$. It can be expressed that in their sport life, women experience injuries due to insufficient flexibility the least. The reason for this may be the fact that women's physiological structure is more prone to flexibility and that they have higher flexibility levels when compared with men. A significant difference at the level of $p<0,001$ was found between types of 
sports in risk factors that caused sport injuries $(p<0,05)$. It can be seen that athletes doing individual sports experience injuries due to type of sport the most $(30,0 \%)$. It can be stated that injuries occurred due to other risk factors (shoes worn, level of education, environmental conditions, etc.) the least $(2,5 \%)$. It can be said that athletes doing individual sports experience low levels of injuries due to parameters that can be expressed as main risk factors. In terms of risk factors that caused injuries in team sports, it was found that the highest number of injuries occurred due to opponent players $(36,6 \%)$. The reason for this result can be the fact that since team sports are generally played with balls, unconscious moves to possess the ball can be preparing a basis for the opponents to experience injuries. It can be seen that the least number of injuries in team sports occur due to insufficient flexibility $(2,8 \%)$. It can be stated that due to flexibility, athletes doing team sports experience almost no injuries. The reason for this may be the fact that since an athlete participating in team sports does not need to have top levels of flexibility when compared with athletes doing individual sports, s/he may not be negatively influenced by injuries resulting from insufficient flexibility.

\begin{tabular}{|c|c|c|c|c|c|c|c|}
\hline \multirow[t]{2}{*}{ Parameters } & \multirow[t]{2}{*}{ Percentage } & \multicolumn{3}{|c|}{ Gender } & \multicolumn{3}{|c|}{ Sport branch } \\
\hline & & Men & Women & Total & $\begin{array}{c}\text { Individua } \\
1 \\
\end{array}$ & Team & Total \\
\hline \multirow[t]{2}{*}{ Type of sport } & Number & 150 & 36 & 186 & 72 & 114 & 186 \\
\hline & $\%$ & 32,5 & 17,6 & 25,0 & 30,0 & 26,8 & 28,4 \\
\hline \multirow[t]{2}{*}{ Opponent player } & Number & 120 & 84 & 204 & 48 & 156 & 204 \\
\hline & $\%$ & 26,0 & 41,2 & 33,6 & 20,0 & 36,6 & 28,3 \\
\hline \multirow[t]{2}{*}{ Field area } & Number & 42 & 12 & 54 & 24 & 30 & 54 \\
\hline & $\%$ & 9,1 & 5,9 & 7,5 & 10,0 & 7,0 & 8,5 \\
\hline \multirow[t]{2}{*}{ Previous injuries } & Number & 24 & 18 & 42 & 30 & 24 & 54 \\
\hline & $\%$ & 5,2 & 8,8 & 6,3 & 12,5 & 5,6 & 8,1 \\
\hline \multirow[t]{2}{*}{ Warm-up level } & Number & 48 & 30 & 78 & 12 & 30 & 42 \\
\hline & $\%$ & 10,4 & 14,7 & 11,7 & 5,0 & 7,0 & 6,3 \\
\hline \multirow[t]{2}{*}{ Training frequency } & Number & 6 & 12 & 18 & 42 & 36 & 78 \\
\hline & $\%$ & 1,3 & 5,9 & 2,7 & 17,5 & 8,5 & 11,7 \\
\hline \multirow{2}{*}{$\begin{array}{l}\text { Insufficient } \\
\text { flexibility }\end{array}$} & Number & 24 & 6 & 30 & 6 & 12 & 18 \\
\hline & $\%$ & 5,2 & 2,9 & 4,5 & 2,5 & 2,8 & 2,7 \\
\hline \multirow[t]{2}{*}{ Others $\left(^{*}\right)$} & Number & 48 & 6 & 54 & 6 & 24 & 30 \\
\hline & $\%$ & 10,4 & 2,9 & 8,1 & 2,5 & 5,6 & 4,5 \\
\hline \multirow[t]{2}{*}{ Total } & Number & 462 & 204 & 666 & 240 & 426 & 666 \\
\hline & $\%$ & 100,0 & 100,0 & 100,0 & 100,0 & 100,0 & 100,0 \\
\hline
\end{tabular}

*Shoes worn, Level of education, Environmental conditions

Table 3 shows the data about gender and sport type in terms of athletes' resting time following injuries. No significant difference was found in post-injury resting time in terms of gender $(p>0,05)$. Significant difference was found in post-injury resting time in terms of sport type $(p<0,05)$. It can be seen that total resting time is 7 days or shorter in resting parameters in terms of gender $(57,3 \%)$ and sport type $(57,4 \%)$. It can be seen that in both gender $(7,8 \%)$ and the sport type $(5,4 \%)$, the least occurring period of resting time in total was 8-14 days. In athletes doing individual sports, it was found that the most occurring period of resting time following injury was 7 days and shorter with a rate of $60,0 \%$. The least occurring resting time was 8-14 days with a rate of $5,4 \%$. It can be stated that the mild injuries occurring in athletes doing individual sports can have caused a relatively shorter resting time interval following injury. In teams sports, the most occurring post-injury time interval was 7 days and shorter with a rate of $54,9 \%$. The least occurring period of post-injury resting time was 8-14 days with a rate of $5,6 \%$. It can be stated that most and least occurring resting times in individual and team sports were similar.

The reason for this can be explained with the similarity within the treatment processes of similar injuries in terms of science. 


\begin{tabular}{|c|c|c|c|c|c|c|c|}
\hline \multicolumn{2}{|c|}{ Parameters } & \multirow{2}{*}{\begin{tabular}{|c|} 
Male \\
258 \\
\end{tabular}} & \multirow{2}{*}{$\begin{array}{c}\text { Female } \\
120\end{array}$} & \multirow{2}{*}{\begin{tabular}{|c|} 
Total \\
378 \\
\end{tabular}} & \multirow{2}{*}{$\begin{array}{c}\text { Individua } \\
\mathbf{1} \\
144 \\
\end{array}$} & \multirow{2}{*}{$\begin{array}{c}\text { Team } \\
234 \\
\end{array}$} & \multirow{2}{*}{\begin{tabular}{c|} 
Total \\
378 \\
\end{tabular}} \\
\hline 7 days and shorter & Number & & & & & & \\
\hline & $\%$ & 55,8 & 58,8 & 57,3 & 60,0 & 54,9 & 57,4 \\
\hline \multirow[t]{2}{*}{ 8-14 days } & Number & 36 & 0 & 36 & 12 & 24 & 36 \\
\hline & $\%$ & 7,8 & 0,0 & 7,8 & 5,0 & 5,6 & 5,4 \\
\hline \multirow[t]{2}{*}{ 15-21 days } & Number & 102 & 54 & 156 & 48 & 108 & 156 \\
\hline & $\%$ & 22,1 & 26,5 & 24,3 & 20,0 & 25,4 & 22,7 \\
\hline \multirow[t]{2}{*}{22 days and longer } & Number & 66 & 30 & 96 & 36 & 60 & 96 \\
\hline & $\%$ & 14,3 & 14,7 & 14,4 & 15,0 & 14,1 & 14,5 \\
\hline \multirow[t]{3}{*}{ Total } & Number & 462 & 204 & 666 & 240 & 426 & 666 \\
\hline & $\%$ & 100,0 & 100,0 & 100,0 & 100,0 & 100,0 & 100,0 \\
\hline & & \multicolumn{2}{|c|}{ Chi square:2,77 } & & \multicolumn{3}{|c|}{ Chi square $17,30 \quad \mathrm{p}<0,001$} \\
\hline
\end{tabular}

Table 4 shows the data about post-injury total injured time in terms of gender and sport type. No significant difference was found between gender and type of sport parameters during the time athletes were injured $(p>0,05)$. It can be stated that there is no significant difference in injury times of athletes in terms of gender and type of sport.

\begin{tabular}{llcccccc}
\hline Table 4. Gender and sport type data of amateur athletes by the post-injury injured time \\
\hline Parameters & Male & Female & Total & Individual & Team & Total \\
\hline 0-1 day & Number & 282 & 132 & 414 & 156 & 258 & 414 \\
\cline { 2 - 8 } & $\%$ & 61,0 & 64,7 & 62,8 & 65,0 & 60,6 & 62,8 \\
\hline \multirow{2}{*}{ 2-7 days } & Number & 66 & 18 & 84 & 24 & 60 & 84 \\
& $\%$ & 14,3 & 8,8 & 115 & 10,0 & 14,1 & 12,0 \\
\hline 8 days and longer & Number & 114 & 54 & 168 & 60 & 108 & 168 \\
\cline { 2 - 8 } & $\%$ & 24,7 & 26,5 & 25,6 & 25,0 & 25,4 & 25,2 \\
\hline \multirow{2}{*}{ Total } & Number & 462 & 204 & 666 & 240 & 426 & 666 \\
\hline & $\%$ & 100,0 & 100,0 & 100,0 & 100,0 & 100,0 & 100,0 \\
\hline
\end{tabular}

Table 5 shows the data about the state of training during the time the amateur athletes were injured in terms of gender and sport type. Significant difference was found between the state of training during injury in terms of gender $(p<0,05)$. It can be seen that the athletes partly trained during injury in terms of gender $(50,9 \%)$ and type of sport $(52,1 \%)$. It can be seen that male athletes $(51,9 \%)$ and female athletes $(50,0 \%)$ mostly answered that they partly trained during injury. It can be stated that both genders trained during injury with specific intervals. It can be seen that only a small number of male $(20,8 \%)$ and female $(11,8 \%)$ athletes trained during injury.

Significant difference was found between the athletes' state of training during injury in terms of the type of sport $(p<0,05)$. It can be seen that individual $(55,0 \%)$ and team sport $(49,3 \%)$ athletes mostly stated that they trained partly during injury. It can be seen that only a small number of athletes doing individual $(20,0 \%)$ and team $(16,9 \%)$ sports stated that they trained during injury. In terms of the state of training during injury by gender and the type of sport, a similarity was found that no matter what the athletes' characteristics (gender, type of sport) were, most athletes partly trained. The fact that the athletes did not want to be deprived of recreation activities during injury in terms of not preventing the body from experiencing negativities by many factors (physiological, psychological, etc.) may have caused this result. Although parameters such as the type of sport and gender were taken into consideration in athletes' states of training during injury, it can be seen that very few athletes trained. The fact that they could not train as a result of negativities that occurred during injury may have caused the result that few athletes trained during injury. 


\begin{tabular}{|c|c|c|c|c|c|c|c|}
\hline \multicolumn{2}{|l|}{ Parameters } & Male & Female & Total & Individual & Team & Total \\
\hline \multirow[t]{2}{*}{ I do train } & Number & 96 & 24 & 120 & 48 & 72 & 120 \\
\hline & $\%$ & 20,8 & 11,8 & 16,3 & 20,0 & 16,9 & 18,4 \\
\hline \multirow[t]{2}{*}{ I do train partly } & Number & 240 & 102 & 342 & 132 & 210 & 342 \\
\hline & $\%$ & 51,9 & 50,0 & 50,9 & 55,0 & 49,3 & 52,1 \\
\hline \multirow[t]{2}{*}{ I don't train } & Number & 126 & 78 & 204 & 60 & 144 & 204 \\
\hline & $\%$ & 27,3 & 38,2 & 32,7 & 25,0 & 33,8 & 29,4 \\
\hline \multirow[t]{3}{*}{ Total } & Number & 462 & 204 & 666 & 240 & 426 & 666 \\
\hline & $\%$ & 100,0 & 100,0 & 100,0 & 100,0 & 100,0 & 100,0 \\
\hline & & Chi s & |re:12,04 & $\mathbf{p}<0,05$ & & i squar & \\
\hline
\end{tabular}

Table 6 shows amateur athletes' gender and sport type data by their injury type. Significant difference was found in the injury type of amateur athletes in terms of gender $(p<0,05)$. No significant difference was found in the injury type in terms of the type of sport $(p>0,05)$. In total, the highest number of injury in terms of gender $(44,6 \%)$ and sport type $(41,6 \%)$ was sprain. In total, the lowest number of injury in terms of gender $(9,8 \%)$ and sport type $(8,7 \%)$ was fracture. It can be seen that sprain was common in male athletes $(36,4 \%)$, female athletes $(52,9 \%)$, individual sport athletes $(42,5 \%)$ and team sport athletes. It can be said that the most common injury type in both classifications and subgroups were similar. Whatever the characteristics differentiating between athletes are (gender, type of sport), the reason why the highest number of injury was sprain can be thought as the weak structure and the intense use of joints. It can be seen that the least number of injury athletes were exposed to was fracture in male athletes $(7,8 \%)$ and team sport athletes $(9,0 \%)$. It can be seen that female athletes $(5,9 \%)$ were exposed to dislocation, while individual sport athletes (7,5\%) were exposed to fracture and dislocation. It can take a long time for the injured area to be treated after being exposed to injuries such as fracture and dislocation. Thus, an athlete's being exposed to injuries such as fracture and dislocation can mean a long break to sport life. For this reason, it can be expressed that athletes are more careful to protect from these injuries and thus the least common type of injury is fracture or dislocation.

\begin{tabular}{|c|c|c|c|c|c|c|c|}
\hline Parameters & & Male & Female & Total & Individual & Team & Total \\
\hline \multirow[t]{2}{*}{ Fracture } & Number & 36 & 24 & 60 & 18 & 42 & 60 \\
\hline & $\%$ & 7,8 & 11,8 & 9,8 & 7,5 & 9,9 & 8,7 \\
\hline \multirow[t]{2}{*}{ Dislocation } & Number & 54 & 12 & 66 & 18 & 48 & 66 \\
\hline & $\%$ & 11,7 & 5,9 & 8,8 & 7,5 & 11,3 & 9,4 \\
\hline \multirow[t]{2}{*}{ Sprain } & Number & 168 & 108 & 276 & 102 & 174 & 276 \\
\hline & $\%$ & 36,4 & 52,9 & 44,6 & 42,5 & 40,8 & 41,6 \\
\hline \multirow[t]{2}{*}{ Bruises } & Number & 84 & 24 & 108 & 36 & 72 & 108 \\
\hline & $\%$ & 18,2 & 11,8 & 15 & 15,0 & 16,9 & 15,9 \\
\hline \multirow[t]{2}{*}{ Other } & Number & 120 & 36 & 156 & 66 & 90 & 156 \\
\hline & $\%$ & 26,0 & 17,6 & 21,8 & 27,5 & 21,1 & 24,3 \\
\hline \multirow[t]{3}{*}{ Total } & Number & 462 & 204 & 666 & 240 & 426 & 666 \\
\hline & $\%$ & 100,0 & 100,0 & 100,0 & 100,0 & 100,0 & 100,0 \\
\hline & & $\mathrm{Ch}$ & $46 \quad \mathrm{p}<0$ & & Chi square: 6 & $\mathrm{P}>0,05$ & \\
\hline
\end{tabular}

Table 7 shows the rates of injury areas by gender and sport type parameters. No significant difference was found between genders in terms of the area the athletes had injuries in $(p>0,05)$. Significant difference was found between sport types in terms of the area the athletes had injuries in $(p<0,05)$. In total, it can be seen that the least injured area was shoulders in terms of gender $(6,2 \%)$ and sport type $(7,1 \%)$. In total, it can be seen that the least injured area was wrist and ankle in terms of gender $(36,4 \%)$ and sport type $(36 \%)$. It can be said that in terms of both gender parameter and the sport type variable, the most injured area was wrist and ankle. Table 6 shows that athletes experienced injuries due to 
sprain the most. Thus, this may have caused the most injured area to be wrist and ankle in terms of both variables.

\begin{tabular}{|c|c|c|c|c|c|c|c|}
\hline Parameters & & Male & Female & Total & Individual & Team & Total \\
\hline \multirow[t]{2}{*}{ Wrist and ankle } & Number & 162 & 77 & 239 & 88 & 151 & 239 \\
\hline & $\%$ & 35,1 & 37,7 & 36,4 & 36,7 & 35,4 & 36 \\
\hline \multirow[t]{2}{*}{ Knee } & Number & 90 & 37 & 127 & 43 & 84 & 127 \\
\hline & $\%$ & 19,5 & 18,1 & 18,8 & 17,9 & 19,7 & 18,8 \\
\hline \multirow[t]{2}{*}{ Shoulder } & Number & 30 & 12 & 42 & 24 & 18 & 42 \\
\hline & $\%$ & 6,5 & 5,9 & 6,2 & 10,0 & 4,2 & 7,1 \\
\hline \multirow[t]{2}{*}{ Elbow } & Number & 52 & 24 & 76 & 23 & 53 & 76 \\
\hline & $\%$ & 11,3 & 11,8 & 11,4 & 9,6 & 12,4 & 11 \\
\hline \multirow[t]{2}{*}{ Finger } & Number & 36 & 21 & 57 & 20 & 37 & 57 \\
\hline & $\%$ & 7,8 & 10,3 & 9 & 8,3 & 8,7 & 8,5 \\
\hline \multirow[t]{2}{*}{ Other $\left(^{*}\right)$} & Number & 92 & 33 & 125 & 42 & 83 & 125 \\
\hline & $\%$ & 19,9 & 16,2 & 18 & 17,5 & 19,5 & 18,5 \\
\hline \multirow[t]{3}{*}{ Total } & Number & 462 & 204 & 666 & 240 & 426 & 666 \\
\hline & $\%$ & 100,0 & 100,0 & 100,0 & 100,0 & 100,0 & 100,0 \\
\hline & \multicolumn{4}{|c|}{ Chi square:5,91 $p>0,05$} & \multicolumn{3}{|c|}{ Chi square:9,88 } \\
\hline
\end{tabular}

${ }^{*}$ Cheekbone and collar bone, tendon injury

Table 8 shows the rates of treatment methods during injury in terms of gender and sport type variables. Significant difference was found between treatment methods applied during injury in terms of gender and sport type variables $(\mathrm{P}<0,05)$. In total, when the data were analyzed in terms of gender $(54,3 \%)$ and sport type $(56,0 \%)$, the most commonly applied treatment method was by self and other individuals. It can be said that athletes want to use all the means to make the treatment process more useful or to make the treatment process quicker. Thus, this can have caused most athletes to conduct treatment methods during injury both by self and under doctor control and also with the support of other individuals. It can be seen that the least preferred treatment method during injury is by self in terms of both gender $(18,4 \%)$ and sport type (20,9\%). Considering that it will be correct to advance the treatment process with a scientific method, this may have caused many athletes not to perform their treatment

on their own.

Table 8. Data about the treatment methods applied by amateur athletes during their injury in terms of gender and type of sport

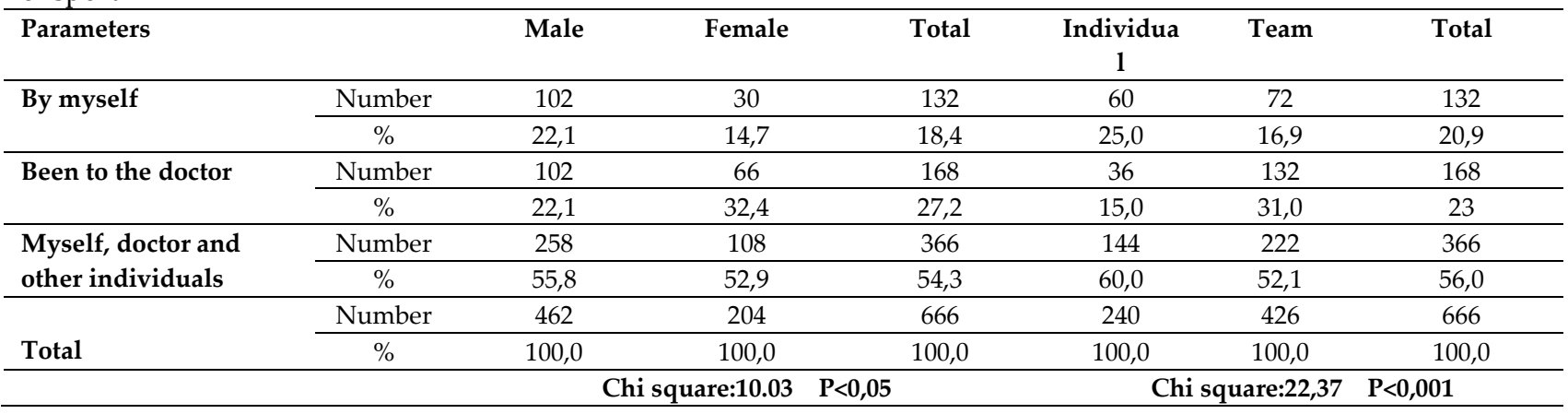

\section{DISCUSSION}

In this study, which examines the frequency of sportive injury in amateur athletes and the factors influencing injuries, the average age of the participants is 21,09 . The average height of the participants in the study was $174,34 \mathrm{~cm}$. The average weight of the participants is 68,11 (Table 1 ).
During intense sportive workout, sport injuries occur due to different reasons (4). In a study conducted by Doğan et al. (6) on the risk factor influencing the injuries of amateur athletes, the factors that caused the least injuries were found as protective equipment, age, gender and garment worn with a rate of $0,95 \%$; while the risk factor that caused the most injuries was type of sport with a rate of $20 \%$ (6). In a study by Bavli (2) which 
examined the association between recklessness levels and state of injury in children in their development age, it was found that the participants experienced injuries due to insufficient training the least with a rate of $1,7 \%$ and due to opponent player the most with a rate of $35,7 \%$ (2). In this study, it can be seen that the risk factor which influenced injury the least was insufficient flexibility with a rate of $2,7 \%$ and opponent player the most with a rate of $33,6 \%$ (Table 2). It can be said that there were differences in the risk factors influencing injury when compared with other studies conducted in terms of the risk factors that caused injury the least. This difference can have resulted from the fact that the risk factors that caused injury the least varied in terms of other parameters rather than main factors.

Minimizing the risk factors for athletes to experience sportive injuries can cause too many socio-economic advantages (6). Sorenson et al. reported that in sport injuries, more than half of the patients started working the next day (19). In a study they examined the risk factors influencing the injuries of amateur athletes, the injuries that required $0-1$ day of resting period constituted $61,9 \%$ of all injuries (6). In addition, in Özgür et al.'s study (14) which examined the frequency of sport injury in volleyball and football players, it was found football players returned to sportive activity in six weeks or longer with a rate of $48,3 \%$, while volleyball players returned to sportive activity in less than a week with an average of $30,4 \%$ (14). In this study, it can be seen that the participants rested for 7 days and less the most (58,8\%) and between 8-14 days the least $(5,4 \%)$ (Table 3). It can be seen that the results of resting time are parallel with the results of other studies. The fact that the types of injury athletes experienced were mild can have caused short resting periods.

Sport injuries can be defined as conditions preventing participation in sport the next day after an injury occurs (9). In Requa et al.'s (17) study which examined the state of injury in adult athletes, the longest period athletes were injured was between 1 and 2 days with a rate of $76 \%$ (17). In the present study, this period is also between 1 and 2 days with a rate of $64,7 \%$ (Table 4 ). In addition, when the athletes' state of training during the time they were injured was examined, it was found that $55 \%$ of the participants trained partly, while $11,8 \%$ of the participants did not train (Table 5). It can be seen that the results of the period athletes were injured are in parallel with the results of other studies. It can be thought that the fact that athletes mostly experienced injuries which will not prevent them from doing sport in high rates may have caused the aforementioned result.

When the types of injuries athletes were exposed to were examined, it was reported in a study by Yamaner et al. (21) which examined the lower extremity injuries of amateur and professional football players that athletes were exposed to sprain $(16,6 \%)$ the most (21). In another study on a similar topic by Özgür et al. (14), it was found that the participants were exposed to sprain the most with a rate of $38,5 \%(14)$. Similarly, in the present study it can be seen that the participants were exposed to sprain the most $(52,9 \%)$ (Table 6$)$. In addition, in terms of the areas of injuries, in a study by Kiratl et al. which examined the association between basketball players' flexibility profiles and injury, it was reported that $46,15 \%$ of the athletes experienced injury in the ankle area (11). In the present study, the highest $(37,7 \%)$ rate of injuries were found in wrists and ankles (Table 7). It can be said that the results are in parallel with the results of other studies. The fact that injuries will easily occur in areas which can be expressed as sensitive areas of the human body can have caused sprain to be the highest form of injury seen. Activity level of the participants, their branches, race, and factors affecting muscular strength or tendon and joint stability were among the confounding factors that should be evaluated in future studies along with other effective factors in ankle, knee and pelvis regions (20).

As a conclusion, it can be seen that the area in which the most injuries were seen was wrist and ankle. In addition, it can be said that the highest type of injury seen was sprain. It can be stated that the athletes trained partly during injury. What is more, it can be expressed that following injury, the resting period included 7 days or shorter and that the athletes mostly remained injured between 0 and 1 day. It can also be stated that the risk factor that influenced injury most was injury resulting from opponent players. It can be seen that the treatment method applied during injury took place both by the athlete's being his/her own doctor and also by being under the supervision of a doctor and with the advices of other people. In order to minimize the types of injury athletes experience, athletes and trainers should be informed through various ways (seminar, applied training, etc). 


\section{REFERENCES}

1. Akgün N. Spor hekimliği kavramı, Spor Hekimliği. Ankara: Maya Matbaacılık Yayıncılık Ltd. Şti, 1992: 1-3.

2. Bavli Ö, Kozanoğlu E. Adolesan Basketbolcularda Mevkilere Göre Yaralanma Türleri ve Nedenleri, Fırat Üniversitesi Sağlık Bilimleri Tıp Dergisi, 2008: 22(2): 77-80.

3. Brito J, Malina R, Seabra A, Massada J, Soares J, Krustrup P. Injuries in Portuguese soccer players during training and match play. J Athl Train. 2012;47:191-7.

4. Can S. Beden eğitimi ve spor yüksek okullarindaki öğrencilerin karşilaştiklari spor yaralanmalari, Dağ Sporlarina İlişkin Riskin Algilanması: 59.

5. Conn JM, Annest JL, Gilchrist J. Sports and recreation related injury episodes in the US population, 1997-99. Inj Prev. 2003;9(2):117-123.

6. Doğan AA, O.İ., Amatör Sporcularda Sportif Yaralanma Sıklığı ve Yaralanmalara Etki Eden Faktörler. Karadeniz Tıp Dergisi, 1995: 3(8): 96-99.

7. Dvorak J., Junge A. Soccer injuries: a review on incidence and preventionSports Med, 2004: 34 (13) pp. 929-938

8. Ergen, E, Spor Yaralanmalarından Korunma. Atatürk Üniversitesi BESYO, Tıp Fakültesi FTR ABD Spor, 2002.

9. Ergün S. Elit Taekwondocularda Ayak Bilene Uygulanan Bandajın Kuvvete Etkisi, Selçuk Üniversitesi Sağlık Bilimleri Enstitüsü Yüksek Lisans Tezi, 2008, Konya.

10. Hasçelik Z. Spor Sakatlıkları Nasıl Engellenebilir. Başbakanlık GSGM Eğitim Dairesi Yayınları, Ankara, 1990.

11. Kiratli, E, Sanioğlu A. Basketbolcularin esneklik profillerive sakatlanmayla olan ilişkisi. Selçuk Üniversitesi Sosyal Bilimler Enstitüsü Dergisi, 2005(14): 393-400.
12. Lam MHS, Tung K, Man DP, Lee KY, Lei Y, Flint SW and Peake D. Examining Lower Limb Injuries among Male Amateur Soccer Player. Journal of Yoga \& Physical Therapy. 2017, 7:1

13. Özdemir M. Spor Yaralanmalarında Korunma ve Rehabilitasyon İlkeleri. Çizgi Kitabevi, 2004: 48-50.

14. Özgür, B.O., T. Özgür, and M. Aksoy, Voleybol Ve Futbolcularda Spor Sakatlığına Rastlama Sıklığı. İstanbul Üniversitesi Spor Bilimleri Dergisi, 2016: 6(3): 50-55.

15. Özşahin F, Akpınar N. Spor travmalarında etio-patogenez, Spor Hekimliği Dergisi,, 1978: 3(4): 9.

16. Price RJ, Hawkins RD, Hulse MA, Hodson A. The Football Association medical research programme: an audit of injuries in academy youth football. Br J Sports Med. 2004;38(4):466471.

17. Requa, R.K., L.N. DeAvilla, and J.G. Garrick, Injuries in recreational adult fitness activities. The American Journal of Sports Medicine, 1993: 21(3): 461-467.

18. Shanmugann C, Maffulli N. Sports Injuries in Children. Br Med Bul, 2008: 86: 33-57.

19. Sorensen, C. and S. Sonne-Holm, Social costs of sports injuries. British journal of sports medicine, 1980: 14(1): 24

20. Şener O. A., Durmaz M. Effect of Sport Training and Education on Q Angle in Young Males and Females, Journal of Education and Training Studies, 2019: 7 (7):17-21.

21. Yamaner, F., Osman İmamoğlu, Abdullah Güllü, Dursun Güler, Mustafa Gümüş, Cem Tevfik Akalın, Alparslan Kartal. Amatör ve profesyonel futbolcuların alt ekstremite yaralanmalarının araştırılması. Genel Tip Dergisi, 2009: 19(3). 